\title{
Removal of Real Textile Dyes by Electrocoagulation/Electroflotation in a Pilot External-Loop Airlift Reactor
}

\author{
H. Chenik ${ }^{1,2}$, M. Elhafdi ${ }^{1,2}$, A. Dassaa ${ }^{1,2}$, A. H. Essadki ${ }^{1 *}$, M. Azzi ${ }^{2}$ \\ ${ }^{1}$ Ecole Supérieure de Technologie, Laboratoire de Génie des Procédés et Environnement, Casablanca, Morocco \\ ${ }^{2}$ Faculté des Sciences Aïn Chock, Laboratoire Interface Matériau Environnement, Casablanca, Morocco \\ Email: "essadki@est-uh2c.ac.ma
}

Received July 1, 2013; revised August 3, 2013; accepted September 5, 2013

Copyright (C) 2013 H. Chenik et al. This is an open access article distributed under the Creative Commons Attribution License, which permits unrestricted use, distribution, and reproduction in any medium, provided the original work is properly cited.

\begin{abstract}
This paper studied the efficiency of electrocoagulation/electroflotation in removing colour from real textile wastewater by using aluminum and iron electrodes in an innovative pilot external-loop airlift reactor of $150 \mathrm{~L}$. The reactor was designed to operate in batch and continuous modes. The real effluent contained $90 \%$ of disperse dye and $10 \%$ of reactive dye. A complete flotation of pollutants with acceptable mixing was achieved in this reactor using only the overall liquid recirculation induced by $\mathrm{H}_{2}$ microbubbles. The treatment of these discharges was easier using electrodes of iron rather than aluminum. The optimal initial $\mathrm{pH}$ was 10 for both aluminum and iron electrodes. By using iron electrodes, the maximum decolourisation efficiency and COD reduction efficiency reached respectively $96 \%$ and $65 \%$ for 90 minutes of treatment. Similarly, by using aluminum electrodes, the maximum decolourisation efficiency reached $90 \%$, COD reduction reached $51 \%$ for 120 minutes of treatment. In the case of an initial $\mathrm{pH}$ slightly different to 10 , the required time to reach $90 \%$ ranged from double to triple.
\end{abstract}

Keywords: Pilot External Airlift Reactor; Electrocoagulation; Electroflotation; Real Textile Dye

\section{Introduction}

A large amount of water and chemicals are used in the textile industry for finishing and dying processes. Therefore, toxic compounds contained in dye wastewater should to be removed before it can be discharged.

Different conventional methods consisting of various combinations of biological, physical and chemical methods [1-5] were used in order to deal with textile wastewater. The biological treatment is certainly cheaper but less efficient than other methods [5]. The high efficiency of chemical oxidation can be an alternative such as UV/ $\mathrm{H}_{2} \mathrm{O}_{2}, \mathrm{O}_{3}$, and adsorption using activated carbon but the costs of these methods is relatively high.

Many papers demonstrated that the electrocoagulation (EC) technique could be an effective tool for treatment of textile wastewaters leading to high removal efficiency with relatively low cost [6]. EC consists of creating metallic hydroxides flocks within the wastewater by electrodissolution of soluble anodes namely the iron or aluminum. As the electrocoagulation/electroflotation is faster

\footnotetext{
*Corresponding author.
}

than electrocoagulation/sedimentation, the engineering approach should reach flotation with minimum energy consumption.

The literature reveals that any systematic approach design has been proposed to deal with the complex interactions between electrochemistry, colloidal forces and hydrodynamics that govern the behavior of EC reactors. Most papers use laboratory-scale EC cells in which magnetic stirring is adjusted experimentally and the separation step by floatation/sedimentation is not studied. Mollah et al. [7] described six typical configurations for industrial EC cells and reported their respective advantages and drawbacks.

Essadki et al. [8] have proposed an external-loop airlift reactor (20 1) to realize EC and electroflotation. The bubbles hydrogen produced at the cathode are used to float the flocks. The difference in density between the riser section, containing the liquid-gas mixture and the downcomer containing only the liquid, induces a flow of liquid which performs agitation. Another study [9] concerning defluoridation was carried out using batch electrocoagulation/electroflotation (EC/EF) in two reactors for com- 
parison purpose: a stirred tank reactor (STR) close to a conventional EC cell and an external-loop airlift reactor (ELAR). The respective influences of current density, initial concentration and initial $\mathrm{pH}$ on the efficiency of defluoridation were investigated. The same trends were observed in both reactors, but the efficiency was higher in the STR at the beginning of the electrolysis, whereas similar values were usually achieved after 15 min operation.

In a previous work, Balla et al. [10] used the same reactor to treat reactive, disperse and mixture dyes. The colour efficiency was between $70 \%$ and $90 \%$ and COD efficiency reached $78 \%$. However, the design of the external-loop airlift reactor proposed has a drawback concerning the continuous operation. Thus, the residence time distribution (RTD) measurements [11] revealed that a large portion of the effluent flows directly through the outlet without being processed. To overcome this problem another reactor was designed to work on batch and continuous modes.

The objective of this study is to treat a real textile dye in an innovative pilot external-loop airlift reactor functioning in a batch mode and also as a continuous reactor.

\section{Materials and Methods}

\subsection{Reactor Design}

The reactor designed as an airlift reactor with external loop has a maximum capacity of 150 liters (L). The detail of the reactor is shown in Figure 1.

The total volume of liquid in the reactor depends on the height $h$ (1) of the liquid in the separator and can vary between 100 to $150 \mathrm{~L}$.

All compartments of the reactor have a parallelepiped shape with square cross sections.

The riser is the section in which the gas phase is sparged. The riser (13) has a cross sectional side (2) equal to $20.5 \mathrm{~cm}$ and $103.8 \mathrm{~cm}$ height. The downcomer has a cross sectional side equal to $10.2 \mathrm{~cm}$ and $48.3 \mathrm{~cm}$ height. The riser-to-downcomer cross-sectional ratio $\left(\mathrm{A}_{\mathrm{r}} /\right.$ $A_{d}$ ) is about 4 , this value corresponds to a reaction taken place only in the riser section.

The distance between the vertical axis of the riser and downcomer is $76.8 \mathrm{~cm}$ which limits the recirculation of bubbles/particles from the riser into the downcomer.

The riser and the downcomer are connected at the bottom by a junction with a length of $111 \mathrm{~cm}$ and 10.2 $\mathrm{cm}$ as a cross-sectional side. This connecting column (4) is inclined at an angle of $120^{\circ}$ relative to the vertical to minimize the pressure losses compared to a horizontal connecting. The particles that may escape from the flock contained in the free surface of the reactor by a possible partial erosion of the flock can be retrieved again by the hydrogen bubbles and reach again the flock.

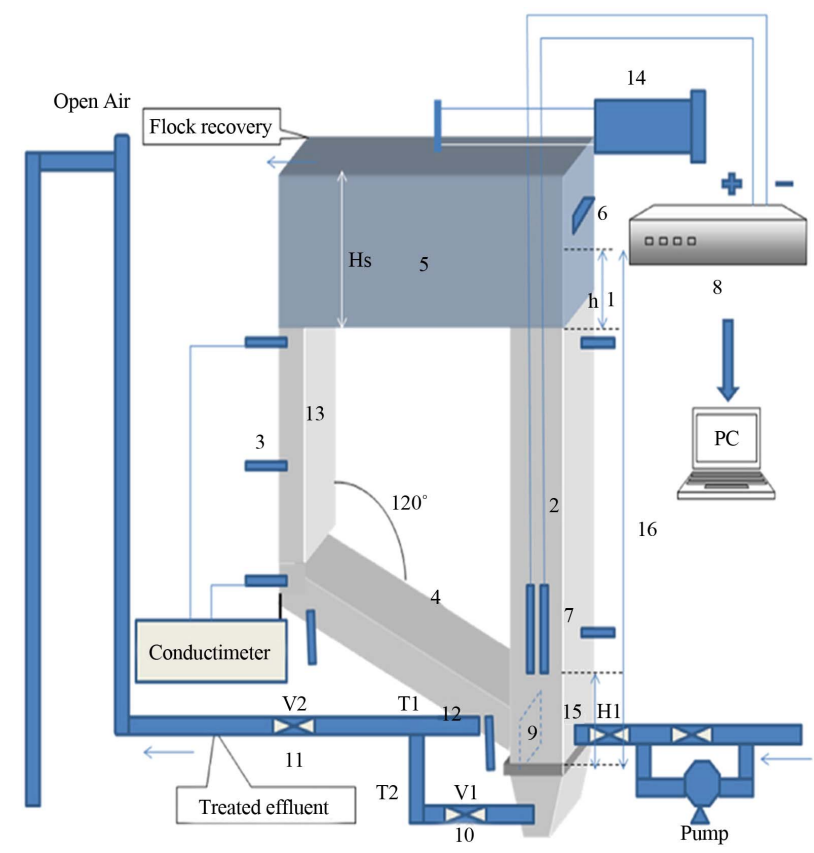

Figure 1. External-loop airlift reactor (1: level of the effluent in the separator, 2: riser section, 3: conductivity probe, 4: connecting column, 5: separation section, 6: slot, 7: electrodes, 8: generator, 9: region closed to the liquid passage, 10: valve $V_{1}, 11$ : valve $V_{2}, 12$ : tube $T_{1}, 13$ : downcomer section, 14: scraping system, 15: $\mathrm{H}_{1}$ : electrodes position).

The gas separator of height $\mathrm{H}_{\mathrm{S}}=40 \mathrm{~cm}$ (5) has a length of $107.5 \mathrm{~cm}$, and a width of $20.5 \mathrm{~cm}$. A slot (6) is located in the part of the downcomer to allow the flock formed overflow from the reactor or to be recovered by a scraping system (14).

Two readily available aluminum or iron flat electrodes of rectangular shape $(232 \mathrm{~mm} \times 165 \mathrm{~mm} \times 1 \mathrm{~mm})$ were used as the anode and the cathode, which corresponds to $\mathrm{S}=1050 \mathrm{~cm}^{2}$ electrode surface area. The distance between electrodes was e $=20 \mathrm{~mm}$, which is a typical value in EC cells. The electrodes were placed in the riser, parallel to the main flow direction to minimize pressure drop in the riser and maximize the recirculation velocity. The axial position of the electrode could also be varied in the column. The distance $\left(\mathrm{H}_{1}\right)$ between the bottom of the electrodes and the bottom of the riser was chosen $\mathrm{H}_{1}=54$ $\mathrm{cm}$ according to the induced liquid velocity that permit the stability of the flock. EC was conducted in the intensiostat mode, using a digital DC power "Power supply EA-9080 PSI", with cables having $8 \mathrm{~mm}^{2}$ in section as recommended by the technical manual in order to minimize the Joule effect. For large amperage, the ground is considered. Current intensity I, does not exceed $20 \mathrm{~A}$.

Two options are considered: a batch operation and continuous operation. The choice of one or other of the options can be achieved by handling valves.

For batch operation: 
The characteristic of this external-loop airlift reactor is that the riser column is not directly connected with the connecting column: region closed to the passage of liquid from the downcomer (9). Valve $V_{1}(10)$ is open and the valve $\mathrm{V}_{2}(11)$ is closed. Loops produced by the liquid are made via the tubes $T_{1}, T_{2}$ and valve $V_{1}$.

For continuous operation:

Valve $V_{1}$ is closed and valve $V_{2}$ is open. The treated effluent exits the reactor through the tube $T_{1}$ (12), the valve $V_{2}$ and another tube that is open to the air to adjust the liquid level in the reactor.

The effluent is recovered without flock since the later is formed by electroflotation in the separator section and recovered by overflow (6) or by a scraping system (14).

By this process, the investment cost of installing filtration is avoided. Another advantage is that the stirring, the coagulation and flotation are achieved electrochemically by inserting electrodes in an optimal position in the riser.

\subsection{Methods}

Dye concentration was estimated from its absorbance characteristics in the UV vis range (200 - $800 \mathrm{~nm})$, using the wavelength that provided the maximum intensity ( $\lambda_{\max }=436,525$ and $620 \mathrm{~nm}$ ) by UV-vis spectrophotometer (UV-Visible spectrometer Helios $\gamma$, type Gamma). COD was measured using the standard closed reflux colorimetric method. The $\mathrm{pH}$ was measured with a $\mathrm{pH}$ meter (PHM 220 Radiometer analytical). Initial pH was varied between 8 and 11. Conductivity was determined by a conductivity meter ("Cyberscan 510-cond" "Conductimeter Consort K 120").

To cover the absorbance of various types constituting the mixture, 3 wavelengths were used: 436, 525 and 620 $\mathrm{nm}$. Absorbance was measured every $15 \mathrm{~min}$ in order to determine the time required for the establishment of suitable efficiency.

Colour and COD removal efficiencies $\left(Y_{\mathrm{COL}}, Y_{\mathrm{COD}}\right)$ were expressed as follows:

$$
\begin{gathered}
Y_{\mathrm{COL}}(\%)=\frac{A_{0}-A}{A_{0}} \\
Y_{\mathrm{COD}}(\%)=\frac{(\mathrm{COD})_{0}-\mathrm{COD}}{(\mathrm{COD})_{0}}
\end{gathered}
$$

In Equation (1), $A_{0}$ and $\mathrm{A}$ are respectively the initial absorbance and the absorbance at a certain time.

In Equation (2), (COD) $)_{0}$ and COD are respectively the initial COD and the COD at a certain time expressed in $\mathrm{kg} / \mathrm{L}$.

The real wastewaters have been collected from two ducts, one from acid dyestuff containing reactive dyes, the second one collected from basic dyestuff containing dispersive dyes. The two effluents were conducted to a tank to be mixed.
The percentage of each kind of the dyes is $90 \%$ of dispersive and $10 \%$ of reactive.

The reactive dyes contained Yellow SPD, Red S3B 195, Blue BRF $150 \%$. The dispersive dyes contained Yellow Terasil 4G, Red disperse and Blue Terasil 150\%.

The real wastewaters were provided from ITEX, Textile industry (Casablanca, Morocco). The characteristic of the real wastewaters are shown in Table 1.

The average liquid velocity in the downcomer $\left(\mathrm{U}_{\mathrm{ld}}\right)$ was measured by using the conductivity tracer technique. Two conductivity probes placed in the downcomer section were used to record the tracer concentration resulting from the injection of a saturated $\mathrm{NaCl}$ solution at the top of the downcomer using a data acquisition system (Omega OMB-55 A/D converter) connected to a PC computer. Liquid velocity was estimated using the ration of the mean transit time between the tracer peaks detected successively by the two electrodes and the distance between the probes.

In Section 3, all experiments were conducted with a batch mode.

\section{Results and Discussion}

\subsection{Induced Liquid Velocity}

The driving force for the overall liquid circulation results

\begin{tabular}{|c|c|}
\hline Temperature $\left({ }^{\circ} \mathrm{C}\right)$ & 29.5 \\
\hline $\mathrm{pH}$ & 11.46 \\
\hline Conductivity at $20^{\circ} \mathrm{C}(\mu \mathrm{S} / \mathrm{cm})$ & 1040 \\
\hline BOD5 (mg/l) & 405 \\
\hline $\mathrm{COD}(\mathrm{mg} / \mathrm{L})$ & 951 \\
\hline Total azote NTK: (mg/l) & 8.1 \\
\hline $\mathrm{Cr}(\mathrm{mg} / \mathrm{l})$ & 0.029 \\
\hline $\mathrm{Fe}(\mathrm{mg} / \mathrm{l})$ & 1.15 \\
\hline Total phosphorus (mg/l) & 0.05 \\
\hline $\mathrm{Mn}(\mathrm{mg} / \mathrm{l})$ & 0.201 \\
\hline $\operatorname{Ar}(\mathrm{mg} / \mathrm{l})$ & 0.011 \\
\hline $\mathrm{Cd}(\mathrm{mg} / \mathrm{l})$ & 0.0021 \\
\hline $\mathrm{Zn}(\mathrm{mg} / \mathrm{l})$ & 0.16 \\
\hline $\mathrm{Ni}(\mathrm{mg} / \mathrm{l})$ & 0.019 \\
\hline $\mathrm{Hg}(\mathrm{mg} / \mathrm{l})$ & 0.0003 \\
\hline $\mathrm{Cu}(\mathrm{mg} / \mathrm{l})$ & 0.024 \\
\hline $\mathrm{Se}(\mathrm{mg} / \mathrm{l})$ & 0.008 \\
\hline $\mathrm{Pb}(\mathrm{mg} / \mathrm{l})$ & 0.037 \\
\hline
\end{tabular}

Table 1. Characteristics of real dyes effluent. 
from the gas hold-up difference between the riser $\left(\varepsilon_{\mathrm{r}}\right)$ and the downcomer $\left(\varepsilon_{\mathrm{d}}\right)$, and also from the dispersion height $\left(h_{D}\right)$. In this work, the gas phase is electrochemicallygenerated. So $h_{D}$ is related to the axial position of the electrodes in the riser $\left(\mathrm{H}_{1}\right)$. In a previous paper [8], the liquid velocity in the downcomer $\mathrm{U}_{\mathrm{ld}}$ was correlated to the dispersion height and current density (j).

As expected, Figure 2 shows that the liquid velocity increases with current density.

The influence of the axial position of electrodes is also shown. In all cases the flock remains stable (no erosion or break-up) as the velocity is less than in the previous work $\left(\mathrm{U}_{\mathrm{ld}}>8 \mathrm{~cm} \cdot \mathrm{s}^{-1}\right)$ [8]. In this reactor the pressure drop is important allowing to weak values of liquid velocity due to the presence of valves and tubes.

The axial position of electrodes was then chosen to be equal to $\mathrm{H}_{1}=54 \mathrm{~cm}$ corresponding almost to the middle position of electrodes in the riser.

Complete flotation was achieved by this position allowing to good mixing using only electrochemically generated $\mathrm{H}_{2}$ bubbles.

Decolourization efficiency, COD abatement were investigated in terms of initial $\mathrm{pH}$ and electrolysis time in order to determine the optimum operating conditions for decolourization efficiency of real textile effluent.

Preliminary experiments suggested that 16 A was a sufficient current intensity to achieve a good decolourisation. This intensity corresponds to a current density of $31.4 \mathrm{~mA} / \mathrm{cm}^{2}$.

Figure 3 shows the decolourization efficiency as a function of time for an initial $\mathrm{pH}$ of 10 . The asymptotic value of decolourization efficiency $(96 \%)$ was reached at a time of 90 minutes. Negative values of the removal indicate the green colour appeared during a certain time of the electrolysis. The green colour corresponds to the formation of the $\mathrm{Fe}(\mathrm{OH})_{2}$ according to the following reactions:

Anode: $\mathrm{Fe} \rightarrow \mathrm{Fe}^{2+}+2 \mathrm{e}^{-}$

Cathode: $2 \mathrm{H}_{2} \mathrm{O}+2 \mathrm{e}^{-} \rightarrow 2 \mathrm{OH}^{-}+\mathrm{H}_{2}(\mathrm{~g})$

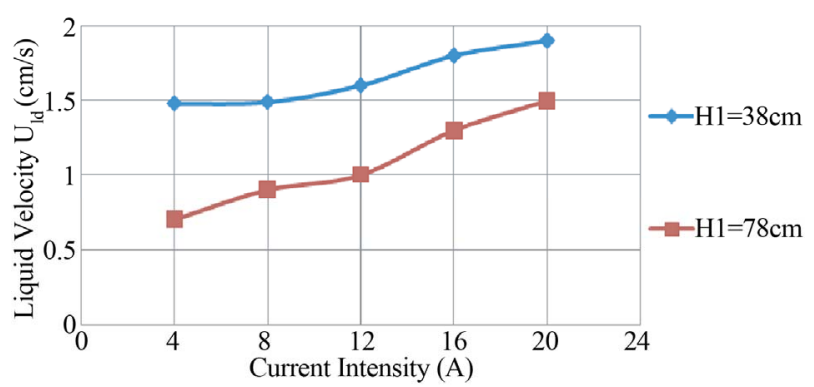

Figure 2. Influence of the axial position of the electrodes $\left(\mathrm{H}_{1}\right)$ and current intensity on the overall liquid recirculation $U_{L d}$ (h = $25 \mathrm{~cm}$, initial pH: 8; conductivity: $\kappa=2.4 \mathrm{mS} / \mathrm{cm}$ ).

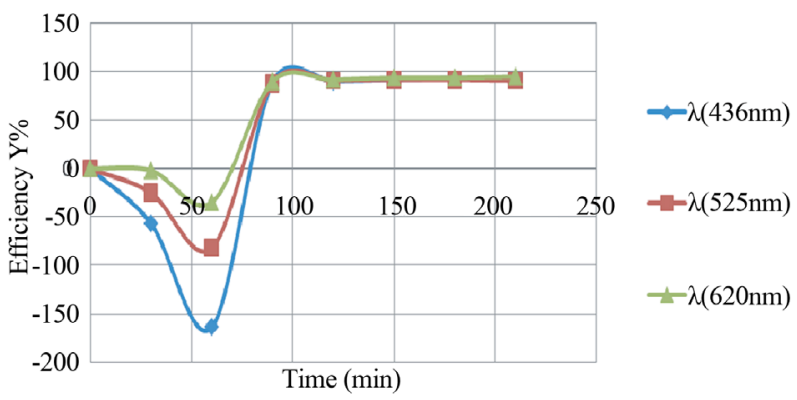

Figure 3. Evolution of the decolourization efficiency versus time (iron electrodes, $\mathrm{pHi}=10, \mathrm{j}=31.4 \mathrm{~mA} / \mathrm{cm}^{2}$ ).

So: $\mathrm{Fe}^{2+}+2 \mathrm{OH}^{-} \rightarrow \mathrm{Fe}(\mathrm{OH})_{2}(\mathrm{~s})$

$\mathrm{Fe}(\mathrm{OH})_{2}$ is then oxidized to allow the formation of $\mathrm{Fe}(\mathrm{OH})_{3}$.

For an initial $\mathrm{pH}$ of 8 , the time required to reach 93\% as an asymptotic value is 180 minutes, whereas for an initial $\mathrm{pH}$ of 11, 190 minutes was the time to reach $90 \%$ as decolourisation efficiency (not shown).

The influence of the initial $\mathrm{pH}$ on COD removal is illustrated in Figure 4.

An optimum COD abatement is also obtained for an initial $\mathrm{pH}$ which was equal to 10 . The values of COD abatement corresponded to the times required to reach the asymptotic value.

During the batch EC, the $\mathrm{pH}$ changed. Its evolution depended to the initial $\mathrm{pH}$. In this work, the $\mathrm{pH}$ increased to reach 12 as shown in Figure 5.

This indicates that EC process exhibits some buffering capacity because of the balance between the production and the consumption of $\mathrm{OH}^{-}$[12], which prevents high change in $\mathrm{pH}$. The buffering $\mathrm{pH}$ seems to reach 12 . This buffering value is not the same as found by Essadki et al. [8] probably because of the use of another type of dye.

\subsection{Treatment of Real Wastewater: Using Al Electrodes}

Figure 6 shows the decolourization efficiency as a function of time for an initial $\mathrm{pH}$ of 10 . The asymptotic value of decolourization efficiency $(90 \%)$ was reached at a time of 130 minutes for wavelengths corresponding to $436 \mathrm{~nm}$ and $525 \mathrm{~nm}$, whereas the decolourisation efficiency reached $95 \%$ in the case of a wavelength corresponding to $620 \mathrm{~nm}$. This indicates that kinetics of decolourisation differs according to the component.

For an initial $\mathrm{pH}$ of 8 , the asymptotic value reached $61 \%$ in a required time of 300 minutes, whereas for an initial $\mathrm{pH}$ of 11, 120 minutes was the time to reach only $22 \%$ as decolourisation efficiency as illustrated in Figure 7.

The corresponding COD evolution is shown in Figure 8. For an initial $\mathrm{pH}$ equal to $10 \%, 51 \%$ is the maximum COD reduction, whereas the reduction COD efficiency 


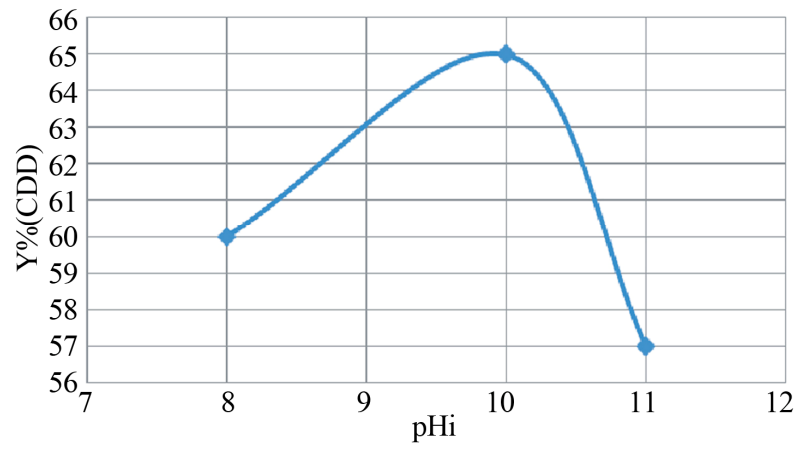

Figure 4. Evolution of the COD abatement according to the initial pH: pHi (iron electrodes, $\mathrm{j}=31.4 \mathrm{~mA} / \mathrm{cm}^{2}$ ).

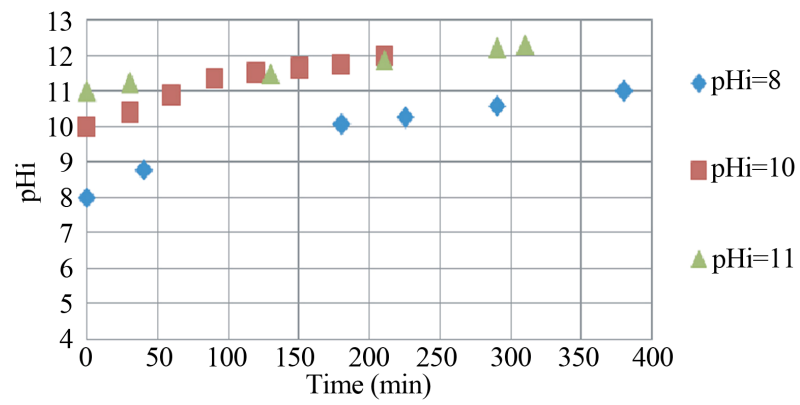

Figure 5. Evolution of $\mathrm{pH}$ values during EC for different values of initial $\mathrm{pH}$ (Iron electrodes, conductivity: $\kappa=2.4$ $\mathrm{mS} / \mathrm{cm}$, current density: $\mathrm{j}=31.4 \mathrm{~mA} / \mathrm{cm}^{2}$ ).

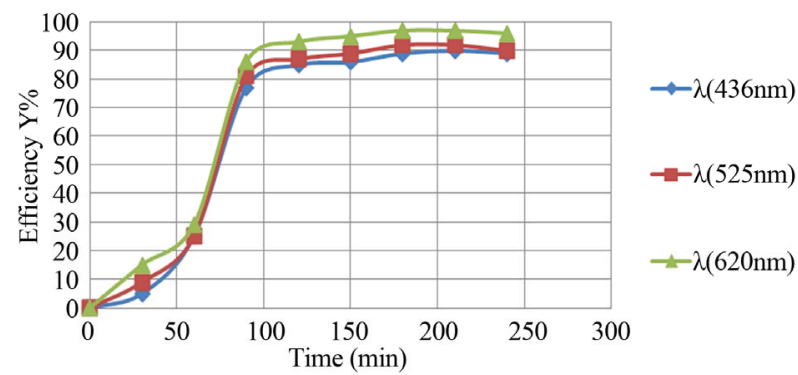

Figure 6. Evolution of the decolourization efficiency versus time (aluminum electrodes, $\mathrm{pHi}=10, \mathrm{j}=31.4 \mathrm{~mA} / \mathrm{cm}^{2}$ ).

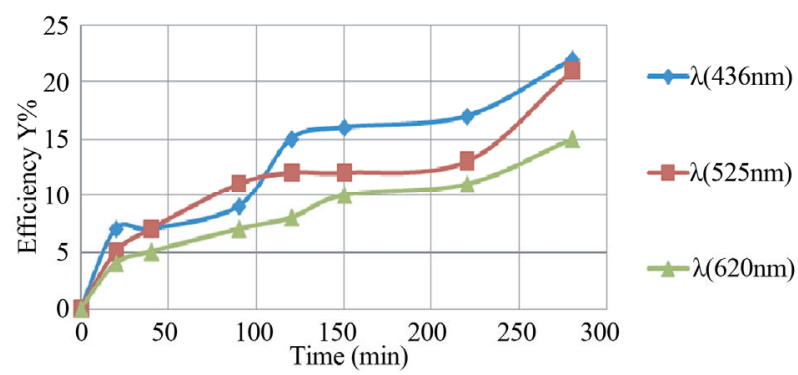

Figure 7. Evolution of the decolourization efficiency versus time (aluminum electrodes, $\mathrm{pHi}=11, \mathrm{j}=31.4 \mathrm{~mA} / \mathrm{cm}^{2}$ ).

does not exceed $37 \%$ for an initial $\mathrm{pH}$ equal to 11 .

The evolution of $\mathrm{pH}$ during time is different to the case of iron electrodes. Thus, Figure 9 shows that $\mathrm{pH}$

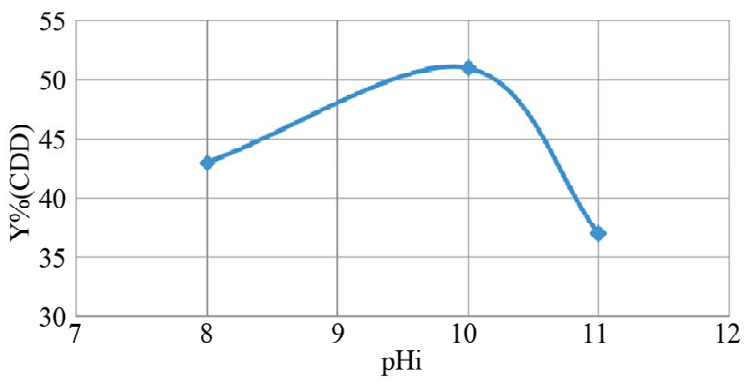

Figure 8. Evolution of the COD abatement according to the initial pH: pHi (aluminum electrodes, $\mathrm{j}=31.4 \mathrm{~mA} / \mathrm{cm}^{2}$ ).

increased for initial $\mathrm{pH}$ between 8 and 10 and decreased for an initial $\mathrm{pH}$ of 11 to reach 10.65 after 200 minutes. This demonstrates that EC process exhibits some buffering capacity as indicated above.

\section{Continuous Mode}

Continuous operation was then undertaken for a flowrate taking into account the decolourisation kinetic. In order to keep a residence time greater or equal to one hour and half, 60 liter per hour was chosen for the effluent flow-rate $(\mathrm{Q})$.

Figure 10 shows the COD abatement versus time. The asymptotic value reaches $50 \%$ in 90 minutes. The initial $\mathrm{pH}$ is 10 .

A complete flotation was observed and demonstrated by measuring samples at the exit of the reactor. The turbidity and the UV measurement show that the samples contained only the liquid phase.

\section{Liquid and Flock Analysis}

Supplementary information is provided by induced coupled plasma (ICP) analysis to determine the total soluble $\mathrm{Al}$ or Fe content in water. The sample of liquid was chosen after a time corresponding to $90 \%$ as efficiency decolourisation.

The measured $\mathrm{Al}$ concentration is $0.402 \mathrm{mg} / \mathrm{L}$, whereas the iron concentration is only $0.068 \mathrm{mg} / \mathrm{L}$. The presence of residual $\mathrm{Al}$ species above the limit of $0.2 \mathrm{mg} / \mathrm{L}$ in water is not specific to this work. It has been observed in the effluents of conventional coagulation process based on alum for which aluminum as a coagulant is often used in large excess in comparison to this work [13-15].

The flock formed is also analyzed in order to determine the amount of $\mathrm{Al}$ or $\mathrm{Fe}$ contained in the flock. The sludge was collected for times corresponding to $90 \%$ efficiency for both $\mathrm{Al}$ electrode and iron electrodes. The sludge was dried in oven with a temperature of $120^{\circ} \mathrm{C}$, then calcined using $500^{\circ} \mathrm{C}$ as temperature of the oven.

The samples were then solubilized using $\mathrm{HCl}$ or not. The solution was then analyzed using ICP technique.

Table 2 summarized the results confirming that the 
Table 2. Amount of Al and Fe in the flock.

\begin{tabular}{cccccc}
\hline Samples & Electrodes used & flock & Weight of flock solubilized (g) & $\begin{array}{c}\text { Volume of HCl added (ml) } \\
\text { (mg/liters) By ICP technique }\end{array}$ & $\begin{array}{c}\text { Results of Al or Fe concentration } \\
\text { (me }\end{array}$ \\
\hline 1 & Fe & dried & 1 & 10 & $\mathbf{2 2 7 4}$ \\
2 & Al & dried & 1 & 0 & $\mathbf{2 0 3 7 . 5}$ \\
3 & Fe & Calcined & 1 & 0 & $\mathbf{4 1 4 6 . 4}$ \\
4 & Al & Calcined & 1 & 0 & $\mathbf{3 2 7 0 . 9}$ \\
\hline
\end{tabular}

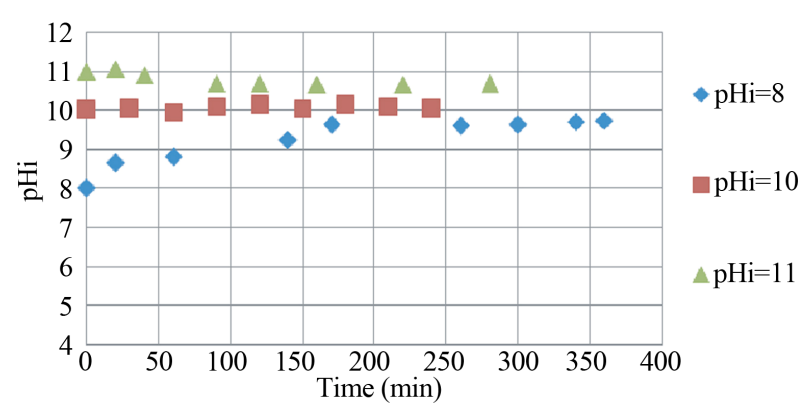

Figure 9. Evolution of $\mathrm{pH}$ values during EC for different values of initial pH (aluminum electrodes, conductivity: $\boldsymbol{\kappa}=$ $2.4 \mathrm{mS} / \mathrm{cm}$, current density: $\mathrm{j}=31.4 \mathrm{~mA} / \mathrm{cm}^{2}$ ).

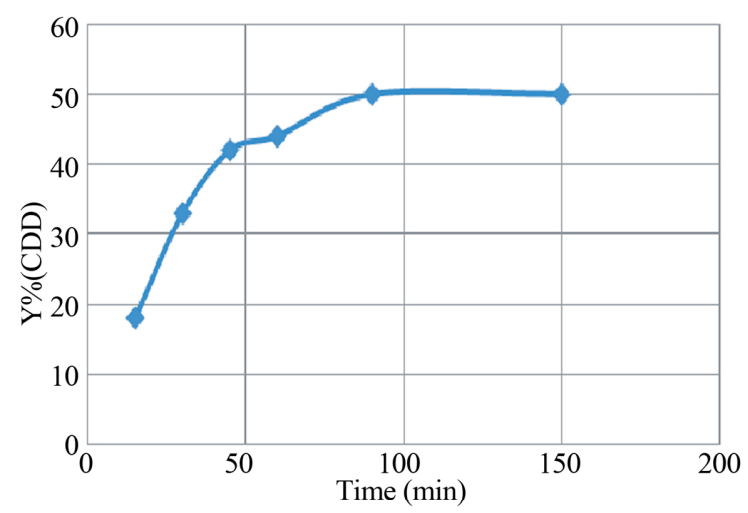

Figure 10. Evolution of the COD abatement versus time: (iron electrodes, $\mathrm{j}=31.4 \mathrm{~mA} / \mathrm{cm}^{2}, \mathrm{Q}=60 \mathrm{l} / \mathrm{h}$ ).

amount of the iron in the flock is greater than aluminum. This confirms the results of the remaining soluble $\mathrm{Al}$ or iron content in water. The adsorption of dyes is more efficient in iron than in aluminium.

\section{Conclusions}

As a conclusion, elctrocoagulation/electroflotation has been successfully realised in a pilot modified externalloop airlift reactor to achieve a complete flotation with good mixing induced by only tiny bubbles generated electrochemically by water electrolysis. The reactor worked with batch mode and also with the continuous mode giving a promising process.

The sensitivity of the initial $\mathrm{pH}$ on the performance of $\mathrm{EC}$ is demonstrated in this work. As in conventional re- actor, $\mathrm{pH}$ adjustment is needed before $\mathrm{EC}$ in airlift reactors, in order to achieve a compromise between best coagulation and best flotation. The optimum range may however vary as a function of electrode material and dye structure.

Hence the control of the initial $\mathrm{pH}$ before EC treatment is necessary to minimize environmental remediation costs and make the process more efficient.

For our case, adsorption may proceed on $\mathrm{Al}(\mathrm{OH})_{3}$ or on the monomeric $\mathrm{Al}(\mathrm{OH})_{4}^{-}$anion or on $\mathrm{Fe}(\mathrm{OH})_{3}$ (as $\mathrm{pH}$ is greater than 4$)$, depending on the dye chemical structure.

The use of iron electrodes is better than the use of aluminium electrodes due to the presence of reactive dyes even at weak proportion $(10 \%)$ in the real textile effluent. This confirmed the results found in the previous work [10] demonstrating that iron shown more efficiency for removing colour for reactive and mixed dyes. The ICP analysis confirms this tendency.

When initial $\mathrm{pH}$ was 10 , COD abatement reached $65 \%$, and the colour efficiency reached 96 during 90 minutes. For initial pH slightly different to 10 , the time required for acceptable efficiency is double or triple.

This study was focusing in the engineering aspect to start the basis of a pilot reactor design in order to realize complete flotation of the flock allowing to recovering the treated effluent without need to filtration installation.

\section{REFERENCES}

[1] R. W. Peters, T. J. Walker, J. E. Eriksen, T. K. Cheng, Y. $\mathrm{Ku}$ and W. M. Lee, "Wastewater Treatment-Physical and Chemical Methods," Journal of the Water Pollution Control Federation, Vol. 57, 1985, pp. 503-517.

[2] J. S. Do and M. L. Chen, "Decolorization of Dye Containing Solutions by Electrocoagulation," Journal of Applied Electrochemistry, Vol. 24, No. 8, 1994, pp. 785790.

[3] J. Q. Jiang and J. D. Graham, "Enhanced Coagulation Using Al/Fe(III) Coagulants: Effect of Coagulant Chemistry on the Removal of Color-Causing NOM," Environmental Technology, Vol. 17, 1996, pp. 937-950.

[4] Y. M. Slokar and A. M. Le Marechal, "Methods of Decoloration of Textile Wastewaters," Dyes Pigments, Vol. 37, No. 4, 1998, pp. 335-356. 
http://dx.doi.org/10.1016/S0143-7208(97)00075-2

[5] A. J. Greaves, D. A. S. Phillips and J. A. Taylor, "Correlation between the Bio Elimination of Anionic Dyes by an Activated Sewage Sludge with Molecular Structure. Part 1: Literature Review," JSDC, Vol. 115, 1999, pp. 363365.

[6] M. Bayramoglu, M. Eyvaz and M. Kobya, "Treatment of the Textile Wastewater by Electrocoagulation: Economical Evaluation," Chemical Engineering Journal, Vol. 128, No. 2-3, 2007, pp. 155-161. http://dx.doi.org/10.1016/j.cej.2006.10.008

[7] M. Y. A. Mollah, R. Morkovsky, J. A. G. Gomes, M. Kesmez, J. R. Parga and D. L. Cocke, "Fundamentals, Present and Future Perspectives of Electrocoagulation," Journal of Hazardous Materials, Vol. 114, No. 1-3, 2004, pp. 199-210. http://dx.doi.org/10.1016/j.jhazmat.2004.08.009

[8] A. H. Essadki, M. Bennajah, B. Gourich, C. Vial, M. Azzi and H. Delmas, "Electrocoagulation/Electroflotation in an External-Loop Airlift Reactor-Application to the Decolorization of Textile Dye Wastewater: A Case Study," Chemical Engineering and Processing, Vol. 47, No. 8, 2008, pp. 1211-1223. http://dx.doi.org/10.1016/j.cep.2007.03.013

[9] A. H. Essadki, B. Gourich., C. Vial, H. Delmas and M. Bennajah, "Defluoridation of Drinking Water by Electrocoagulation/Electroflotation in a Stirred Tank Reactor with a Comparative Performance to an External-Loop Airlift Reactor," Journal of Hazardous Materials, Vol. 168, No. 2-3, 2009, pp. 1325-1333. http://dx.doi.org/10.1016/j.jhazmat.2009.03.021
[10] W, Balla, A. H. Essadki, B. Gouricha, A. Dassaa, H. Chenik and M. Azzi, "Electrocoagulation/Electroflotation of Reactive, Disperse and Mixture Dyes in an ExternalLoop Airlift Reactor," Journal of Hazardous Materials, Vol. 184, No. 1-3, 2010, pp. 710-716. http://dx.doi.org/10.1016/j.jhazmat.2010.08.097

[11] A. H. Essadki, B. Gourich, C. Vial and H. Delmas, "Residence Time Distribution Measurements in an External-Loop Airlift Reactor: Study of the Hydrodynamics of the Liquid Circulation Induced by the Hydrogen Bubbles," Chemical Engineering Science, Vol. 66, No. 14, 2011, pp. 3125-3132. http://dx.doi.org/10.1016/j.ces.2011.02.063

[12] G. Chen, "Electrochemical Technologies Inwastewater Treatment," Separation and Purification Technology, Vol. 38, No. 1, 2004, pp. 11-41. http://dx.doi.org/10.1016/j.seppur.2003.10.006

[13] V. A. Glembotskii, A. A. Mamakov, A. M. Ramanov and V. E. Nenno, Proceedings of the 11th International Mineral Processing Congress, Cagliari, 20-26 April 1975, pp. 562-581.

[14] N. Adhoum, L. Monser, N. Belkhal and J.-E. Belgaied, "Treatment of Electroplating Wastewater Containing $\mathrm{Cu}^{2+}, \mathrm{Zn}^{2+}$ and $\mathrm{Cr}(\mathrm{VI})$ by Electrocoagulation," Journal of Hazardous Materials, Vol. 112, No. 3, 2004, pp. 207213. http://dx.doi.org/10.1016/j.jhazmat.2004.04.018

[15] Meenakshi and R. C. Maheshwari, "Fluoride in Drinking Water and Its Removal," Journal of Hazardous Materials, Vol. 137, No. 1, 2006, pp. 456-463. http://dx.doi.org/10.1016/j.jhazmat.2006.02.024 